\title{
KEEFEKTIFAN MODEL PEMBELAJARAN KOOPERATIF TIPE TALKING STICK PADA MATERI LINGKARAN SISWA KELAS VIII MTs NURUL IMAN
}

\author{
Laila Aisyah \\ Pendidikan Matematika, Fakultas Ilmu Pendidikan, Universitas Hasyim Asy'ari \\ lailaaisyah99@gmail.com \\ Siti Khabibah \\ Pendidikan Matematika, Fakultas Ilmu Pendidikan, Universitas Hasyim Asy'ari \\ khabibah_khabibah@yahoo.com \\ Nihayatus Sa'adah \\ Pendidikan Matematika, Fakultas Ilmu Pendidikan, Universitas Hasyim Asy'ari \\ nihayahsyakir@gmail.com
}

\begin{abstract}
Abstrak
Penelitian ini di latarbelakangi oleh fakta bahwa guru di MTs Nurul Iman masih menggunakan ceramah sebagai satu-satunya metode pembelajaran. Pembelajaran tersebut dapat mengakibatkan siswa kurang antusias ketika pembelajaran, banyak siswa yang kurang memahami materi serta banyak siswa yang diam dan malu bertanya. Hal tersebut mengakibatkan hasil belajar siswa rendah. Dengan menggunakan pembelajaran kooperatif tipe talking stick diharapkan dapat membuat siswa aktif dalam pembelajaran. Tujuan penelitian ini adalah untuk mendeskripsikan keefektifan model pembelajaran kooperatif tipe talking stick pada materi lingkaran yang ditinjau dari aktivitas belajar siswa, hasil belajar siswa dan respon siswa. Rancangan penelitian ini menggunakan One-Shot Case Study. Jenis penelitian ini yaitu analisis deskriptif dengan pendekatan kuantitatif. Subjek penelitian ini adalah 14 siswa. Teknik pengumpulan data menggunakan metode observasi, tes dan angket dengan menggunakan instrumen lembar observasi aktivitas siswa, lembar tes hasil belajar dan lembar angket respon siswa. Hasil penelitian menunjukkan bahwa: (1) Aktivitas belajar siswa tergolong aktif dengan hasil persentase 64,3\%. (2) Hasil belajar siswa tidak tuntas dengan hasil persentase 42,9\%. (3) Respon siswa yaitu positif dengan hasil persentase secara klasikal yaitu 77,8\%.
\end{abstract}

Kata Kunci: pembelajaran, kooperatif, talking stick, lingkaran

\begin{abstract}
This research is motivated by the fact that in MTs Nurul Iman, the teacher fully used only the lecturing method in the learning process. This type of learning makes students to be less enthusiastic in learning process, many students do not understand what the teacher explained and most of students are silent and embarrassed to ask the question. It implies that the achievement of students is low. By using the talking stick type of cooperative learning, it is expected that the students be active in learning process. The purpose of this study was to describe the effectiveness of the talking stick type cooperative learning model on the circle material in terms of student learning activities, student learning outcomes and student responses. This research design uses a one-shot case study. This type of research is descriptive analysis with a quantitative approach. The subjects of this study were 14 students. The data collection technique used the method of observation, tests and questionnaires using the instrumen of student activity observation sheets, learning outcomes test sheets and student response questionnaire sheets. The results showed that: (1) students learning activities were classified as active with a percentage of $64,3 \%$. (2) srudent learning outcomes are not complete with a percentage of $42,9 \%$. (3) the students response is positive with a classical percentage result of $77,8 \%$.
\end{abstract}

Keywords: cooperative learning, talking stick, circle 


\section{PENDAHULUAN}

Pendidikan merupakan salah satu kebutuhan manusia yang paling mendasar. Manusia selalu mencari cara baru untuk pendidikan yang lebih baik agar dapat mengarah pada kemajuan teknologi dan ilmu pengetahuan. Pemerintah selalu berupaya untuk meningkatkan kualitas pendidikan melalui pembelajaran yang ada di sekolah. Apabila pembelajaran yang dilakukan berkualitas tentunya akan menghasilkan generasi yang berkualitas pula. Hal ini sejalan dengan Ma'rup \& Firdaus (2020) bahwa pendidikan sangat perlu untuk dikembangkan sebab pendidikan yang berkualitas dapat meningkatkan kualitas bangsa.

Pembelajaran merupakan suatu proses interaksi yang terjadi antara guru dan siswa serta lingkungan dalam kegiatan belajar mengajar yang terstruktur dan terencana untuk mencapai tujuan pembelajaran. Interaksi yang terjadi dapat terjadi dari siswa dengan siswa atau siswa dengan guru. Hal ini sejalan dengan Hermawan (2014) pembelajaran adalah proses dua arah, yaitu belajar dan mengajar. Belajar dilakukan oleh siswa sedangkan mengajar dilakukan oleh seorang guru sebagai pendidik. Sejalan dengan pendapat Sagala (2013) bahwa pembelajaran merupakan proses dua arah. Mengajar dilakukan oleh guru sebagai pendidik dan belajar dilakukan oleh siswa sebagai peserta didik.

Matematika merupakan ilmu dasar yang berperan penting dalam kehidupan sehari-hari serta kemajuan ilmu pengetahuan dan teknologi. Sejalan dengan Langi, Tahmir, dan Rahman (2016) yang mengatakan bahwa matematika sangat berperan penting dalam perkembangan peradaban manusia dan pola pikir seseorang, sehingga matematika diperlukan dalam kehidupan sehari-hari serta dalam menghadapi kemajuan IPTEK.

Berdasarkan wawancara dengan guru matematika MTs Nurul Iman yang diperoleh bahwa sebagian siswa kurang antusias ketika dilakukan pembelajaran. Banyak siswa yang tidak dapat menjawab pertanyaan karena kurang memahami materi yang disampaikan oleh guru dan banyak siswa yang diam dan tidak mau bertanya ketika ada materi yang kurang dipahami saat proses pembelajaran. Hal tersebut dapat mengakibatkan hasil belajar menjadi rendah. Beberapa masalah tersebut muncul karena kurangnya variasi model pembelajaran yang diterapkan oleh guru.

Berdasarkan masalah tersebut, perlu diadakan perbaikan dalam proses pembelajaran. Salah satu cara untuk meningkatkan hasil belajar dan keaktifan siswa yaitu guru dapat menggunakan model pembelajaran yang ada dengan memilih model pembelajaran sesuai dengan materi yang akan diajarkan.

Model pembelajaran adalah bentuk pembelajaran yang menggambarkan kegiatan dari awal hingga akhir yang disajikan secara khas oleh guru (Fathurrohman, 2015). Dalam hal ini, model pembelajaran yang digunakan tidak berpusat pada guru (teacher centered) tetapi berpusat pada siswa (student centered). Salah satu model pembelajaran yang dapat digunakan adalah model pembelajaran kooperatif tipe talking stick. Hal ini sejalan dengan penelitian Reza (2018) tentang penerapan model pembelajaran kooperatif tipe talking stick yang menunjukkan bahwa siswa lebih aktif dalam proses pembelajaran dibandingkan menggunakan pembelajaran konvensional. Model pembelajaran kooperatif tipe talking stick merupakan suatu model pembelajaran yang menitikberatkan pada aktivitas belajar siswa, karena siswa belajar bersama teman kelompoknya. Keadaan tersebut dapat menimbulkan rasa tanggung jawab siswa terhadap pencapaian hasil belajar baik secara individual maupun kelompok dan siswa mampu mengembangkan potensi yang tersimpan dalam dirinya sekaligus mampu menerapkan pengetahuan dan pengalamannya sehingga siswa lebih aktif belajar.

Berdasarkan uraian di atas, peneliti tertarik untuk melakukan penelitian tentang penggunaan model pembelajaran kooperatif tipe talking stick pada mata pelajaran matematika. Peneliti memilih model pembelajaran kooperatif tipe talking stick dikarenakan guru di sekolah tempat penelitian masih menggunakan metode 
konvensional sehingga membuat siswa kurang aktif dalam proses pembelajaran. Selain itu, penggunaan tongkat dapat mengurangi tingkat kegaduhan siswa karena tongkat tersebut dijalankan berurutan sesuai dengan baris siswa. Dengan penggunaan model pembelajaran kooperatif tipe talking stick diharapkan dapat membuat siswa aktif dalam proses pembelajaran, karena siswa dilatih untuk berani mengemukakan pendapat serta dapat menciptakan suasana belajar yang menyenangkan dalam pembelajaran.

\section{METODE}

Penelitian ini merupakan penelitian kuantitatif dengan metode analisis deskriptif kuantitatif. Rancangan penelitian ini adalah pre-Experimental design dengan bentuk desain One-Shot Case Study. Populasi dalam penelitian ini adalah siswa MTs Nurul Iman dan sampel penelitian ini adalah siswa kelas VIII MTs Nurul Iman yang berjumlah 14 siswa.

Teknik pengumpulan data yang digunakan adalah metode observasi, metode tes dan metode angket. Metode observasi digunakan untuk mengetahui aktivitas siswa selama pembelajaran berlangsung. Metode tes digunakan untuk memperoleh data hasil belajar siswa. Metode angket digunakan untuk mengetahui respon siswa menggunakan model pembelajaran koopertaif tipe talking stick. Teknik analisis data dilakukan menggunakan analisis statistik deskriptif. Analisis ini bertujuan untuk mendeskripsikan aktivitas siswa, hasil belajar siswa dan respon siswa.

\section{HASIL DAN PEMBAHASAN}

Pada penelitian ini, pengambilan data dilakukan di MTs Nurul Iman pada tanggal 2 Juni 2021, diperoleh data hasil penelitian antara lain sebagai berikut:

\section{Aktivitas belajar siswa}

Hasil observasi aktivitas belajar siswa di analisis sesuai dengan penilaian pengamat yang mengikuti berjalannya pembelajaran dari awal hingga akhir. Adapun aspek yang diamati yaitu kegiatan visual, kegiatan lisan, kegiatan mendengarkan dan kegiatan menulis.
Data hasil analisis aktivitas siswa diperoleh bahwa kegiatan visual yang meliputi Siswa membaca LKS dan permasalahan yang diberikan, Siswa memperhatikan penjelasan guru serta Siswa memperhatikan teman saat presentasi. Hasil persentasenya yaitu $83,3 \%$ yang masuk kategori sangat aktif. Kegiatan lisan yang meliputi Siswa bertanya kepada teman/guru, Siswa menyampaikan pendapat/saran serta Siswa berani menjawab ketika mendapat giliran tongkat. Hasil persentasenya yaitu $42,9 \%$ yang masuk kategori cukup. Kegiatan mendengarkan yang meliputi Siswa mendengarkan teman yang melakukan presentasi, Siswa mendengarkan pendapat teman ketika diskusi serta Siswa mendengarkan jawaban teman yang mendapat giliran tongkat. Hasil persentasenya yaitu $73,8 \%$ yang masuk kategori aktif. Kegiatan menulis yang meliputi Siswa menuliskan hasil kerja, Siswa mencatat materi serta Siswa menuliskan kesimpulan. Hasil persentasenya yaitu $59,5 \%$ yang masuk kategori cukup. Berdasarkan uraian tersebut, maka aktivitas siswa selama pembelajaran dikatakan aktif dengan persentase $64,3 \%$.

\section{Hasil belajar siswa}

Tes hasil belajar siswa terdiri dari 3 soal uraian. Data hasil belajar adalah sebagai berikut:

Tabel 1 Analisis Hasil Belajar

\begin{tabular}{|l|l|c|c|}
\hline No & Nama & Nilai & Keterangan \\
\hline 1 & BO & 51 & Tidak Tuntas \\
\hline 2 & DAR & 100 & Tuntas \\
\hline 3 & DS & 51 & Tidak Tuntas \\
\hline 4 & EY & 65 & Tidak Tuntas \\
\hline 5 & KU & 44 & Tidak Tuntas \\
\hline 6 & MBS & 53 & Tidak Tuntas \\
\hline 7 & MAMLH & 83 & Tuntas \\
\hline 8 & MFM & 29 & Tidak Tuntas \\
\hline 9 & MZD & 10 & Tidak Tuntas \\
\hline 10 & MAM & 23 & Tidak Tuntas \\
\hline 11 & NWA & 100 & Tuntas \\
\hline 12 & NQ & 90 & Tuntas \\
\hline 13 & SAR & 80 & Tuntas \\
\hline 14 & N & 75 & Tuntas \\
\hline
\end{tabular}


Berdasarkan hasil analisis tampak bahwa terdapat 6 siswa yang tuntas dan 8 siswa siswa yang tidak tuntas. Rata-rata nilai posttest yaitu 61 dan persentase siswa tuntas secara klasikal yaitu 42,9\%. Karena persentase siswa tuntas secara klasikal kurang dari $75 \%$ maka pembelajaran menggunakan model kooperatif tipe talking stick belum tuntas.

\section{Respon siswa} berikut:

Data respon siswa adalah sebagai

Tabel 2 Analisis Respon Siswa

\begin{tabular}{|c|c|c|c|}
\hline Pernyataan & \%Ya & \% Tidak & Ket. \\
\hline 1 & $100 \%$ & $0 \%$ & Positif \\
\hline 2 & $100 \%$ & $0 \%$ & Positif \\
\hline 3 & $78,6 \%$ & $21,4 \%$ & Positif \\
\hline 4 & $7,1 \%$ & $92,9 \%$ & Positif \\
\hline 5 & $100 \%$ & $0 \%$ & Positif \\
\hline 6 & $0 \%$ & $100 \%$ & Positif \\
\hline 7 & $42,9 \%$ & $57,1 \%$ & Negatif \\
\hline 8 & $57,1 \%$ & $42,9 \%$ & Negatif \\
\hline 9 & $0 \%$ & $100 \%$ & Positif \\
\hline \multicolumn{4}{|c|}{}
\end{tabular}

Pernyataan:

1: Saya senang melakukan pembelajaran dengan diterapkan model pembelajaran talking stick.

2: Tes hasil belajar yang diberikan sangat jelas sehingga membuat saya paham apa yang harus saya sampaikan.

3: LKS yang diberikan adalah LKS baru, sehingga saya tertarik untuk melakukan diskusi.

4: Tes hasil belajar yang diberikan sudah pernah saya ketahui sehingga membuat saya kurang tertarik mengerjakan.

5: Bahasa yang digunakan dalam LKS jelas.

6: Bahasa yang digunakan dalam tes hasil belajar kurang jelas.

7: Tampilan LKS yang disajikan sangat menarik sehingga saya tertarik untuk mengerjakan.

8: Tampilan tes hasil belajar kurang menarik.

9: Saya tidak berminat mengikuti pembelajaran

\section{DAFTAR PUSTAKA}

Fathurrohman, M. 2015. Model-Model Pembelajaran Inovatif : Alternatif Desain Pembelajaran yang Menyenangkan. Jogjakarta: Ar-Ruzz Media. selanjutnya seperti yang baru saya ikuti.

Berdasarkan tabel di atas, dapat diketahui bahwa hasil analisis respon siswa menunjukkan siswa senang mengikuti pembelajaran dengan model baru. Hal ini ditunjukkan dengan hasil angket respon pada pernyataan pertama yaitu positif.

Berdasarkan tabel di atas, hasil analisis data respon siswa diketahui bahwa terdapat 7 pernyataan bernilai positif dan 2 pernyataan bernilai negatif. Secara klasikal persentase respon siswa yaitu $77,8 \%$. Karena persentase hasil respon siswa lebih dari 50\% maka secara klasikal pembelajaran dikatakan positif.

\section{SIMPULAN}

Berdasarkan hasil penelitian mengenai pembelajaran kooperatif tipe talking stick, diperoleh beberapa simpulan yaitu aktivitas belajar siswa menggunakan model pembelajaran kooperatif tipe talking stick pada materi lingkaran siswa kelas VIII MTs Nurul Iman tergolong kategori aktif dengan persentase $64,3 \%$. Hasil belajar siswa menggunakan model pembelajaran kooperatif tipe talking stick tidak tuntas. Terdapat 6 dari 14 siswa yang tuntas hasil belajarnya dengan persentase $42,9 \%$. Respon siswa terhadap pembelajaran dengan menggunakan model pembelajaran kooperatif tipe talking stick pada materi lingkaran siswa kelas VIII MTs Nurul Iman yaitu $77,8 \%$. Dari 9 pernyataan terdapat 7 pernyataan bernilai positif dan 2 pernyataan bernilai negatif. Karena hasil respon siswa lebih dari $50 \%$ maka pembelajaran dikatakan positif.

Berdasarkan uraian di atas, terdapat satu indikator yang tidak terpenuhi. Jadi, pembelajaran menggunakan model pembelajaran kooperatif tipe talking stick pada materi lingkaran siswa kelas VIII MTs Nurul Iman tidak efektif.

Hermawan, A. 2014. Konsep Belajar dan Pembelajaran Menurut AL-Ghazali. Jurnal Qathruna Vol.1 No. 1.

Langi, E. L., Tahmir, S., \& Rahman, A. 2016. Efektivitas Penerapan Model Pembelajaran Kooperatif Tipe Talking 
Stick dengan Strategi Mind Mapping dalam Pembelajaran Matematika Siswa Kelas VII SMP Negeri 2 Rantepao. Jurnal Daya Matematis, Volume 4 No. 1, 65-71.

Ma'rup \& Firdaus A.M., 2020. Pembelajaran Matematika dengan Penerapan Model Kooperatif Tipe Talking Stick Terhadap Siswa Kelas
VII SMP. JEMS (Jurnal Edukasi Matematika dan Sains), 79-88.

Reza, I. 2018. Penerapan Model Talking Stick untuk Meningkatkan Keaktifan dan Hasil Belajar IPS Siswa Kelas V MIN 12 Aceh Besar. (Skripsi, Universitas Islam Negeri Ar-Raniry Darussalam, Banda Aceh).

Sagala, S. 2013. Konsep dan Makna Pembelajaran. Bandung: Alfabeta. 